\title{
Biomechanical analysis of operations for chronic ankle instability
}

\author{
Jeseong Ryu ${ }^{1 *}$, Jongsang Son ${ }^{1}$, Youngkoo Lee ${ }^{2}$, Kyungtai Lee ${ }^{3}$, Youngho Kim \\ From 4th Congress of the International Foot and Ankle Biomechanics (i-FAB) Community \\ Busan, Korea. 8-11 April 2014
}

Ankle sprains are one of the most common sports injuries which are about $40 \%$ of total sports injuries and $20 \sim 40 \%$ of them would be progressed to chronic ankle instability (CAI) [1]. Rehabilitation and surgical therapy have been used to treat CAI, and the open modified Brostrm operation $(\mathrm{MBO})$ is the gold standard surgical procedure. There are various evaluation methods in CAI treatments, such as the interview, visual analogue scale (VAS), and the measurement of range of motion (ROM) and the ankle torque. However, in reality, it is difficult to measure the maximum ROM and torque. Therefore, some studies measured ankle ROM and torque with cadaver specimens $[2,3]$. In this study, both open and arthroscopic $\mathrm{MBO}$ were performed on cadavers, and ankle torque and angle were measured during ankle inversion using the axial-torsion testing system.
Ankle stiffness was calculated from measured data, and effects of both operations were compared quantitatively.

For this study, matched pairs of fresh-frozen human cadaver lower leg specimens were obtained from seven males and four females (average age 71.5 (range 58-98) years). Each specimen consisted of the distal half of a leg. The soft tissues were removed from the calcaneus and distal tibiofibular part, except for the ankle joint and ligament. The anterior talofibular ligament (ATFL) and the calcaneofibular ligament (CFL) were transected. The specimens for the arthroscopic and open $\mathrm{MBO}$ were chosen from the left and right legs alternately. Then, each specimen was fixed in the specially-designed jig that was mounted on the axial-torsion fatigue testing system (Instron 8874, Norwood, MA, USA). The test
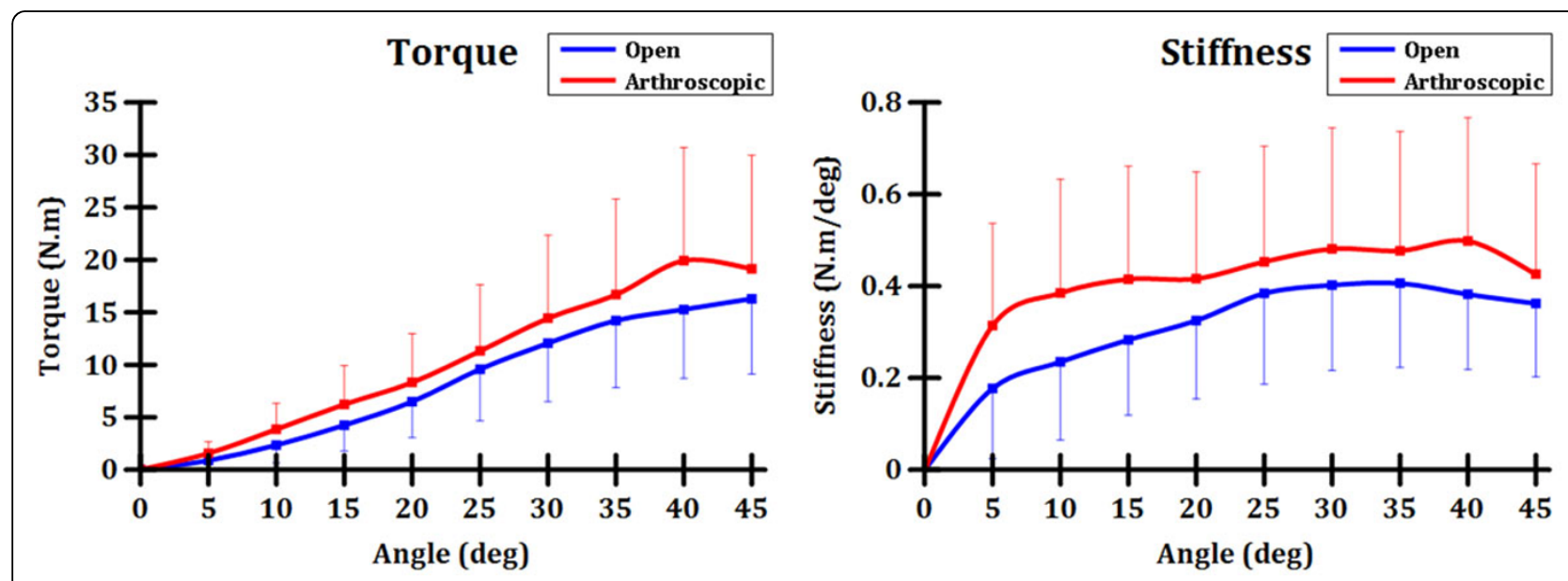

Figure 1 Ankle torque and stiffness during inversion test during open and arthroscopic MBO 
consisted of a single ramp from $0^{\circ}$ to $70^{\circ}$ by inverting the ankle at $5 \%$, while measuring the angular position and resultant torque.

There was no statistical difference in torque to failure between open and arthroscopic MBO. The maximum torque was $16.3 \pm 7.2 \mathrm{~N} \cdot \mathrm{m}$ at $45^{\circ}$ for open $\mathrm{MBO}$ and $19.9 \pm 10.8 \mathrm{~N} \cdot \mathrm{m}$ at $40^{\circ}$ for arthroscopic MBO (Figure 1). Ankle stiffness increased faster in arthroscopic MBO $(0.31 \pm 0.22 \mathrm{~N} \cdot \mathrm{m} / \mathrm{deg})$ than in open MBO $(0.18 \pm 0.15$ $\mathrm{N} \cdot \mathrm{m} / \mathrm{deg})$ in initial inversion range $\left(<5^{\circ}\right)$, but no statistically significant differences were observed. The maximum stiffness was $0.41 \pm 0.18 \mathrm{~N} \cdot \mathrm{m} / \mathrm{deg}$ at $35^{\circ}$ in open $\mathrm{MBO}$ and $0.50 \pm 0.27 \mathrm{~N} \cdot \mathrm{m} / \mathrm{deg}$ at $40^{\circ}$ in arthroscopic MBO (Figure 1).

In this study, biomechanical analysis was performed for operations of CAI and there was no statistically significance in torque and stiffness. In comparison to open $\mathrm{MBO}$, arthroscopic $\mathrm{MBO}$ is good alternative technique for CAI.

\section{Authors' details}

'Department of Biomedical Engineering, Yonsei University, Wonju, Gangwon, 220-710, Republic of Korea. ${ }^{2}$ Department of Orthopedic Surgery,

Soonchunhyang University, Bucheon, Gyeonggi, 420-767, Republic of Korea.

${ }^{3}$ Foot and Ankle Clinic, KT Lee's Orthopedic Hospital, Seoul, 135-820,

Republic of Korea.

Published: 8 April 2014

\section{References}

1. Smith RW, Reischl SF: Treatment of ankle sprains in young athletes. Am J Sports Med 2006, 14:465-71.

2. Birmingham TB, Chesworth BM, Hartsell HD, Stevenson AL, Lapenskie GL, Vandervoort AA: Peak passive resistive torque at maximum inversion range of motion in subjects with recurrent ankle inversion sprains. J Orthop Sports Phys Ther 1997, 25:342-8.

3. Giza E, Nathe R, Nathe T, Anderson M, Campanelli V: Strength of bone tunnel versus suture anchor and push-lock construct in brostrm repair. Am J Sports Med 2012, 40:1419-23.

\section{doi:10.1186/1757-1146-7-S1-A126}

Cite this article as: Ryu et al:: Biomechanical analysis of operations for chronic ankle instability. Journal of Foot and Ankle Research 2014

7(Suppl 1):A126.

\section{Submit your next manuscript to BioMed Central} and take full advantage of:

- Convenient online submission

- Thorough peer review

- No space constraints or color figure charges

- Immediate publication on acceptance

- Inclusion in PubMed, CAS, Scopus and Google Scholar

- Research which is freely available for redistribution

Submit your manuscript at www.biomedcentral.com/submit 